\title{
YIELD RESPONSE FACTOR (KY) FOR WINTER CORN CROP IN THE REGION OF DOURADOS, MS, BRAZIL
}

\author{
Jaqueline A. da Silva ${ }^{1}$, Maiara K. A. Rezende², Danilton L. Flumignan ${ }^{\text {3* }}$
}

$3^{3 *}$ Corresponding author. Empresa Brasileira de Pesquisa Agropecuária - Centro de Pesquisa Agropecuária do Oeste/ Dourados - MS, Brasil. E-mail: danilton.flumignan@embrapa.br | ORCID ID: https://orcid.org/0000-0002-2959-2164

\section{KEYWORDS}

irrigation, water deficit, evapotranspiration, Zea mays.

\begin{abstract}
Plant yield is strongly influenced by the amount of water used by it. In this sense, yield response factor $\left(\mathrm{K}_{\mathrm{y}}\right)$ allows evaluating the decrease in yield as a function of the evapotranspiration that occurs, which may be an important tool for harvest forecasting. Therefore, this study aimed to determine $\mathrm{K}_{\mathrm{y}}$ for winter corn crop grown in the region of Dourados, MS, Brazil. The yield function analysis based on the water factor, which requires actual $\left(\mathrm{Y}_{\mathrm{a}}\right)$ and maximum $\left(\mathrm{Y}_{\mathrm{m}}\right)$ yield data, as well as actual $\left(\mathrm{ET}_{\mathrm{a}}\right)$ and maximum $\left(\mathrm{ET}_{\mathrm{m}}\right)$ evapotranspiration, was used to adjust $\mathrm{K}_{\mathrm{y}}$. $\mathrm{Y}_{\mathrm{m}}$ was assumed to be $8,820 \mathrm{~kg} \mathrm{ha}^{-1}$, while $Y_{a}$ was obtained for each season from the database SIDRA from IBGE. $E_{m}$ and $\mathrm{ET}_{\mathrm{a}}$ were estimated by sequential daily water balance, considering four different sowing dates (all in the off-season). In total, seasons from 2001 to 2013 were analyzed. The high $\mathrm{K}_{\mathrm{y}}$ value obtained (1.22) for winter corn crop showed its high sensitivity to water deficit. Its yield is strongly influenced by water availability so that for every $1 \%$ reduction in evapotranspiration, there is a $1.22 \%$ yield reduction.
\end{abstract}

\section{INTRODUCTION}

In the region of Dourados, Mato Grosso do Sul, MS, Brazil, water deficit caused by short and occasional periods of drought is one of the main causes of agricultural losses. According to Fietz et al. (2017), dry spells often occur in summer crops during a period usually rainy, but with atypical periods of high evaporative demand together with a poor distribution or low supply of precipitations. Losses also occur in the off-season. Although evapotranspiration rates are lower at this period, the precipitation is also lower due to the characteristic drought of autumn and winter, which makes soil water storage often unfavorable.

Winter corn crop is predominant in this region during the off-season. Yield reduction caused by water deficit in the vegetative stage of this crop is relatively low. However, during the flowering and grain-filling period, this reduction is accentuated since, according to Bergamaschi et al. (2004), there is no recovery of its full productive capacity, even with precipitation after the critical period of deficit.

According to Steduto et al. (2012), water has always been the main limiting production factor worldwide in regions where precipitation is insufficient to meet crop water needs. Therefore, the relationship between the level of water deficiency experienced by crops and their yield reduction is evident. Among the existing methods to study this relationship, yield response factor $\left(\mathrm{K}_{\mathrm{y}}\right)$ stands out. This factor was introduced by Doorenbos \& Kassam (1979), who proposed a mathematical model of penalization of the potential crop yield as a function of a reduction in the evapotranspiration rate during the crop cycle. This model endures to the present day and has been reaffirmed by Steduto et al. (2012), consisting of a yield function based on the water factor.

The existence of such a yield function can constitute an important planning and management tool for both producers and the State of Mato Grosso do Sul or even for other actors involved in the production chain of winter corn. This yield function, after a previous and appropriate modeling of $\mathrm{K}_{\mathrm{y}}$ value, could allow predicting crop yield levels from evapotranspiration rates observed during the cycle, which can be estimated using meteorological data and the modeling of the crop coefficient, according to Allen et al. (1998). Thus, this study aimed to determine $\mathrm{K}_{\mathrm{y}}$ for winter corn crop grown in the region of Dourados, MS, Brazil.

\footnotetext{
${ }^{1}$ Universidade Federal da Grande Dourados/ Dourados - MS, Brasil

${ }^{2}$ Universidade Estadual de Maringá/ Maringá - PR, Brasil.

Received in: 1-25-2018

Accepted in: 2-8-2019
} 


\section{MATERIAL AND METHODS}

\section{Study area characterization}

The study was developed aiming at its application to the region of Dourados, although extrapolations can be made to a wider regional context, using Dourados as a reference. According to the Köppen-Geiger classification (Kottek et al., 2006), the local climate is Cfa, a humid subtropical climate. Summer is warm and rainy, while winter is dry and with lower temperatures, including frost. The region is characterized by the variability of climate elements, especially as regards the quantity and distribution of precipitation.

The soil is classified as a Distroferric Red Latosol (Oxisol), being deep and very clay textured (60 to $70 \%$ of clay) (Amaral et al., 2000). The soil water holding capacity (SWHC) for this type of soil is $83 \mathrm{~mm}$ for the first meter of depth. This data originated from several samples collected in the region by Embrapa Western Agriculture and sets up a representative mean value.

\section{Water balance}

The sequential daily water balance was implemented according to the methodology presented in Allen et al. (1998), during the winter corn crop growing season for the region of Dourados, from 2001 to 2013, totaling 13 simulated and analyzed seasons. Simulations considered inputs and outputs of water in the system. Because the winter corn crop was mainly cultivated under rainfed conditions, irrigation value was considered equal to zero. Precipitation was considered as the only water input to the system and analyzed from the data obtained in the database of the weather station of Embrapa Western Agriculture in Dourados on Guia Clima webpage (www.cpao.embrapa.br/clima).

Capillary rise is a very little water input parameter for tropical regions, which often occurs in places with shallow water table and in long periods of drought (Allen et al., 1998). However, this is not the local reality, being therefore disregarded. In addition, surface and subsurface flows of water entering or going out the parcel were considered null because these flows can be considered equivalent, and thus they cancel each other out.

We considered that at the beginning of seasons, the soil was under full water storage, i.e. under field capacity (FC) condition. This practice is in accordance with the regional reality as producers sow when soil water conditions are favorable for germination and early seedling development. In a study to determine the probability of occurrence of water deficit in the same region, Fietz et al. (2001) also considered this same premise.

Sowing was considered at four different periods at each season: February 1 and 15, and March 1 and 15. These dates were adopted due to the agricultural zoning of climate risk for the region and the history of times in which sowing is preferred by producers. It provided a better quality to the study since the sowing at different areas occupies in practice this entire temporal window instead of being carried out punctually during a single period. Therefore, it allowed us to reproduce the reality of the field more assertively.

The length of each winter corn crop phase during the cycle was that recommended by Rezende (2016). Thus,
Phase 1 (initial) lasted 18 days, followed by Phase 2 (growth) with 16 days, Phase 3 (intermediate) with 67 days, and Phase 4 (final) with 39 days. Thus, the total cycle was considered to last 140 days.

The adopted effective root system depth was obtained from previous studies not yet published and performed by Embrapa Western Agriculture. It was obtained by monitoring soil water tension at different depths throughout the crop cycle and identifying layers with water extraction by the winter corn root system. Thus, the effective depth was assumed to be $15 \mathrm{~cm}$ at Phase 1 (initial), $30 \mathrm{~cm}$ at Phase 2 (growth), and $40 \mathrm{~cm}$ at Phases 3 and 4 (intermediate and final, respectively). Therefore, the considered SWHC was 12.5, 24.9 , and $33.2 \mathrm{~mm}$ at these phases, respectively, given that SWHC is $83 \mathrm{~mm}$ for $1 \mathrm{~m}$ of soil.

Simulations considered that whenever soil water storage exceeded SWHC, storage would be limited to SWHC itself. Therefore, excess water consisted of deep drainage, no longer returning to the system. According to Allen et al. (1998), corn tolerates situations where storage is lowered to $45 \%$ of SWHC in its entire cycle. Because of this, soil water depletion factor ( $\mathrm{f}$ ) was defined as 0.55 , i.e. no restriction on evapotranspiration rates would be imposed until $55 \%$ of SWHC was consumed by crop. Considering these values, critical soil water storage was defined as $5.6 \mathrm{~mm}$ for Phase 1 (initial), $11.2 \mathrm{~mm}$ for Phase 2 (growth), and 14.9 $\mathrm{mm}$ for Phases 3 and 4 (intermediate and final, respectively).

Estimates of evapotranspiration were obtained from a historical series of climate data from 2001 to 2013, obtained from the database of the weather station of Embrapa Western Agriculture. The data included air temperature, relative air humidity, solar radiation, and wind speed. They were previously checked for their quality, following the recommendations in Allen (1996). Considering these informations, reference evapotranspiration $\left(\mathrm{ET}_{0}\right)$ was estimated by the Penman-Monteith method, according to parameters set forth in Allen et al. (1998).

The maximum evapotranspiration $\left(\mathrm{ET}_{\mathrm{m}}\right)$ of winter corn crop was determined with the purpose of evaluating its water requirement. Its estimation was carried out by means of [eq. (1)], using values of $\mathrm{ET}_{0}$ and crop coefficient $\left(\mathrm{K}_{\mathrm{c}}\right)$ that were determined experimentally by Rezende (2016), as shown in Table 1.

$$
E T_{m}=E T_{0} \times K_{c}
$$

Where:

$\mathrm{ET}_{\mathrm{m}}$ is the maximum evapotranspiration of winter corn crop $\left(\mathrm{mm} \mathrm{day}^{-1}\right)$;

$\mathrm{ET}_{0}$ is the reference evapotranspiration $\left(\mathrm{mm} \mathrm{dia}^{-1}\right)$, and

$\mathrm{K}_{\mathrm{c}}$ is the crop coefficient of winter corn crop.

TABLE 1. Crop coefficients $\left(\mathrm{K}_{\mathrm{c}}\right)$ of winter corn crop determined by weighing lysimetry in the region of Dourados, MS, Brazil, by Rezende (2016).

\begin{tabular}{lc}
\hline Recommendation & $\mathrm{K}_{\mathrm{c}}$ \\
\hline $\mathrm{K}_{\mathrm{c} \text { initial }}$ & 0.5 \\
$\mathrm{~K}_{\mathrm{c} \text { mid }}$ & 1.2 \\
$\mathrm{~K}_{\mathrm{c} \text { end }}$ & 0.47 \\
\hline
\end{tabular}


The actual evapotranspiration $\left(\mathrm{ET}_{\mathrm{a}}\right)$ was determined by means of Equation (2) by applying the water stress coefficient $\left(\mathrm{K}_{\mathrm{s}}\right)$, which is determined by [eq. (3)].

$$
\begin{aligned}
& E T_{a}=K_{s} \times E T_{m} \\
& K_{s}=\frac{S W H C-D_{r}}{S W H C-R A W}=\frac{S W H C-D_{r}}{(1-f) S W H C}
\end{aligned}
$$

Where:

$\mathrm{ET}_{\mathrm{a}}$ is the actual evapotranspiration of winter corn crop $\left(\mathrm{mm} \mathrm{day}^{-1}\right)$;

$\mathrm{K}_{\mathrm{s}}$ is the water stress coefficient (variable from 0 to 1 );

$\mathrm{ET}_{\mathrm{m}}$ is the maximum evapotranspiration of winter corn crop $\left(\mathrm{mm} \mathrm{day}^{-1}\right)$;

SWHC is the soil water holding capacity $(\mathrm{mm})$;

$\mathrm{D}_{\mathrm{r}}$ is the water depletion in the root zone $(\mathrm{mm})$;

RAW is the readily available water in the root zone (mm), and

$\mathrm{f}$ is the soil water depletion factor $(0.55$ according to Allen et al., 1998).

\section{Yield response factor $\left(K_{\mathrm{y}}\right)$}

The linear regression analysis between the dependent (commercial yield) and the independent variable (evapotranspiration) was used in the determination of $\mathrm{K}_{\mathrm{y}}$. This mathematical procedure allows determining the slope coefficient of the line, which is numerically $\mathrm{K}_{\mathrm{y}}$ itself, as shown in Doorenbos \& Kassam (1979) and represented by [eq. (4)].

$$
\left(1-\frac{Y_{a}}{Y_{m}}\right)=K_{y}\left(1-\frac{E T_{a}}{E T_{m}}\right)
$$

Where:

$$
\begin{aligned}
& \mathrm{Y}_{\mathrm{a}} \text { is the actual yield }\left(\mathrm{kg} \mathrm{ha}^{-1}\right) \text {; } \\
& \mathrm{Y}_{\mathrm{m}} \text { is the maximum yield }\left(\mathrm{kg} \mathrm{ha}^{-1}\right) \text {; } \\
& \mathrm{K}_{\mathrm{y}} \text { is the yield response factor; } \\
& \mathrm{ET}_{\mathrm{a}} \text { is the total actual evapotranspiration of winter } \\
& \text { corn crop cycle (mm), and }
\end{aligned}
$$

$\mathrm{ET}_{\mathrm{m}}$ is the total maximum evapotranspiration of winter corn crop cycle $(\mathrm{mm})$.

By means of water balance simulations, we were able to obtain the values of $\mathrm{ET}_{\mathrm{m}}$ and $\mathrm{ET}_{\mathrm{a}}$ that would be necessary to determine $\mathrm{K}_{\mathrm{y}}$. However, there was still the yield components. Thus, $\mathrm{Y}_{\mathrm{a}}$ values from the aggregated database of the IBGE's Automatic Recovery System (SIDRA) were used. By means of this system, the historical mean yield of winter corn crop from Dourados, was obtained for the period from 2001 to 2013. Most of the winter corn crop of Mato Grosso do Sul is concentrated in this municipality and surroundings, which reached a planted area of 1.7 million ha in 2015, of which 130 thousand ha only in Dourados (IBGE, 2016). The use of this data made possible a sufficiently comprehensive analysis by incorporating in the $Y_{a}$ value the yield resulting from the technological level used in the region and different sowing dates within each season.

In turn, $Y_{m}$ value was assumed to be equal to 8,820 $\mathrm{kg} \mathrm{ha}^{-1}$ and represents the maximum yield that can be reached in the region. This value was obtained from the study developed by Rezende (2016), who evaluated the winter corn crop yield grown under optimized production conditions, as is the case of the region, but using also irrigation.

Although four sowing dates were simulated, the mean of them was considered for analysis of $\mathrm{ET}_{\mathrm{m}}$ and $\mathrm{ET}_{\mathrm{a}}$ values, generating characteristic values for each agricultural season and not each sowing date. In addition, the years of 2001, 2004, and 2011 were removed from $\mathrm{K}_{\mathrm{y}}$ modeling because of crop shortfalls that occurred due to frosts and not water deficit, which implied a mismatch of the modeling, producing obviously incoherent results in these years.

\section{RESULTS AND DISCUSSION}

Precipitations during the off-season in the region of Dourados are in fact very irregular, with the number of rainy days with more than $5 \mathrm{~mm}$ in the different seasons ranging from 12.8 to 28.5 days, representing 2.2 times the difference between them. Even more pronounced is the irregularity in the total precipitation, which ranged from 251.7 to $796 \mathrm{~mm}$, being 3.2 times higher the wettest year when compared to the driest one (Table 2).

In contrast, Table 2 shows that the atmospheric evaporative demand, expressed by $\mathrm{ET}_{0}$, is much less variable (412.1 to $554.2 \mathrm{~mm}$ ) so that the year of highest demand was only 1.3 times higher when compared to that with the lowest demand. It is due to the more regular pattern of the meteorological variables, which are determinant in dictating the rhythm of this demand, i.e. solar radiation, air temperature, relative air humidity, and wind speed. In this same sense, water requirement of winter corn crop cultivated in the region, expressed by $\mathrm{ET}_{\mathrm{m}}$, was also relatively stable (between 387.7 and $535.1 \mathrm{~mm}$ ). Similar behavior was observed in the water consumption that effectively occurred in rainfed crops, which represent the regional reality $\left(\mathrm{ET}_{\mathrm{a}}\right.$ between 174.6 and $\left.278 \mathrm{~mm}\right)$.

Therefore, considering the stability of evapotranspiration rates, when compared to precipitation irregularity, the latter is considered to be the main responsible for the frequent occurrence of water deficiencies in the rainfed production system of winter corn crop in the region. As shown in Table 2, some water deficiency level was observed in all seasons, with values ranging from 122.3 to $352.3 \mathrm{~mm}$. The fact that water deficiency was observed in all the seasons shows the potential and importance of using irrigation in this region since it may be the only agronomic practice capable of allowing winter corn crop to express its productive potential. 
TABLE 2. Number of rainy days with more than $5 \mathrm{~mm}\left(\mathrm{RD}\right.$; days), precipitation $(\mathrm{P} ; \mathrm{mm})$, reference evapotranspiration $\left(\mathrm{ET}_{0}\right.$; $\mathrm{mm})$, maximum evapotranspiration $\left(\mathrm{ET}_{\mathrm{m}} ; \mathrm{mm}\right)$, actual evapotranspiration $\left(\mathrm{ET}_{\mathrm{a}} ; \mathrm{mm}\right)$ and water deficit $(\mathrm{WD}$; mm) for winter corn crop simulated in the region of Dourados, MS, Brazil, from 2001 to 2013. Crop seasons of 2001, 2004, and 2011 were disregarded from the analysis due to the occurrence of frosts. The data of each season consider the mean of the four tested sowing dates, namely: February 1 and 15, and March 1 and 15.

\begin{tabular}{|c|c|c|c|c|c|c|}
\hline Season & $\mathrm{RD}$ & $\mathrm{P}$ & $\mathrm{ET}_{0}$ & $\mathrm{ET}_{\mathrm{m}}$ & $\mathrm{ET}_{\mathrm{a}}$ & WD \\
\hline 2002 & 13.5 & 271.7 & 554.2 & 535.1 & 182.8 & 352.3 \\
\hline 2003 & 16.3 & 432.5 & 495.4 & 471.3 & 258.7 & 212.6 \\
\hline 2005 & 14.3 & 280 & 527 & 502.1 & 183.3 & 318.8 \\
\hline 2006 & 19 & 399 & 459.6 & 431.5 & 221.9 & 209.6 \\
\hline 2007 & 16 & 323.6 & 498 & 473.6 & 194.5 & 279.1 \\
\hline 2008 & 17.5 & 368.6 & 466.2 & 436.5 & 219.1 & 217.4 \\
\hline 2009 & 12.8 & 251.7 & 479.2 & 459.1 & 174.6 & 284.5 \\
\hline 2010 & 14.8 & 364.5 & 484.9 & 455.4 & 198.8 & 256.6 \\
\hline 2012 & 22.5 & 639.6 & 426.7 & 400.3 & 278 & 122.3 \\
\hline 2013 & 28.5 & 796 & 412.1 & 387.7 & 244.3 & 143.4 \\
\hline Mean & 17.5 & 412.7 & 480.3 & 455.3 & 215.6 & 239.7 \\
\hline
\end{tabular}

Table 3 shows that 2002, 2005, and 2009 seasons presented the highest yield reduction, with values of 74.8 , 83.1 , and $85.6 \%$, respectively. This reduction in yield was due to water deficit since the evapotranspiration deficit for these seasons was the highest in the evaluated period, with values of $65.8,63.5$, and $62 \%$, respectively. According to
Bergamaschi \& Matzenauer (2014), pronounced water deficits are capable of affecting several processes, such as sprouting, pollination, nutrient absorption, and translocation of photosynthates. For these authors, these combined effects lead to a little or very expressive yield reduction depending on the deficit level.

TABLE 3. Actual evapotranspiration $\left(\mathrm{ET}_{\mathrm{a}} ; \mathrm{mm}\right)$, maximum evapotranspiration $\left(\mathrm{ET}_{\mathrm{m}} ; \mathrm{mm}\right)$, relative evapotranspiration deficit $\left(1-\mathrm{ET}_{\mathrm{a}} / \mathrm{ET}_{\mathrm{m}}\right)$, actual yield $\left(\mathrm{Y}_{\mathrm{a}}, \mathrm{kg} \mathrm{ha}^{-1}\right)$, maximum yield $\left(\mathrm{Y}_{\mathrm{m}} ; \mathrm{kg} \mathrm{ha}^{-1}\right)$, and relative yield decrease $\left(1-\mathrm{Y}_{\mathrm{a}} / \mathrm{Y}_{\mathrm{m}}\right)$ for winter corn crop seasons analyzed in the region of Dourados, MS, Brazil, from 2001 to 2013. Crop seasons of 2001, 2004, and 2011 were disregarded from the analysis due to the occurrence of frosts.

\begin{tabular}{ccccccc}
\hline Season & $\mathrm{ET}_{\mathrm{a}}$ & $\mathrm{ET}_{\mathrm{m}}$ & $\left(1-\mathrm{ET}_{\mathrm{a}} / \mathrm{ET}_{\mathrm{m}}\right)$ & $\mathrm{Y}_{\mathrm{a}}$ & $\mathrm{Y}_{\mathrm{m}}$ & $\left(1-\mathrm{Y}_{\mathrm{a}} / \mathrm{Y}_{\mathrm{m}}\right)$ \\
\hline 2002 & 182.8 & 535.1 & 0.658 & 2,226 & 8,820 & 0.748 \\
2003 & 258.7 & 471.3 & 0.451 & 4,200 & 8,820 & 0.524 \\
2005 & 183.3 & 502.1 & 0.635 & 1,488 & 8,820 & 0.831 \\
2006 & 221.9 & 431.5 & 0.486 & 3,000 & 8,820 & 0.66 \\
2007 & 194.5 & 473.6 & 0.589 & 2,898 & 8,820 & 0.671 \\
2008 & 219.1 & 436.5 & 0.498 & 3,120 & 8,820 & 0.646 \\
2009 & 174.6 & 459.1 & 0.62 & 1,272 & 8,820 & 0.856 \\
2010 & 198.8 & 455.4 & 0.563 & 4,050 & 8,820 & 0.541 \\
2012 & 278 & 400.3 & 0.306 & 5,022 & 8,820 & 0.431 \\
2013 & 244.3 & 387.7 & 0.37 & 4,986 & 8,820 & 0.435 \\
\hline Mean & 215.6 & 455.3 & 0.518 & $3,226.2$ & 8,820 & 0.634 \\
\hline
\end{tabular}

Yield function resulted in an adjustment of $\mathrm{K}_{\mathrm{y}}$ equal to 1.22 (Figure 1). The model adjustment had a high coefficient of determination $\left(\mathrm{R}_{\text {adjusted }}^{2}\right.$ of 0.88$)$ and significance at $5 \%$ probability, in addition to a low standard error of estimate equal to \pm 0.07 , i.e. $\pm 7 \%$. This $\mathrm{R}^{2}$ value allows us to infer that $88 \%$ of the yield reduction variability of winter corn crop in the region can be explained by the observed evapotranspiration deficit. Moreover, the standard error indicates that the real percentage of this reduction should differ little from that estimated by the model, i.e. $7 \%$ below or above. 


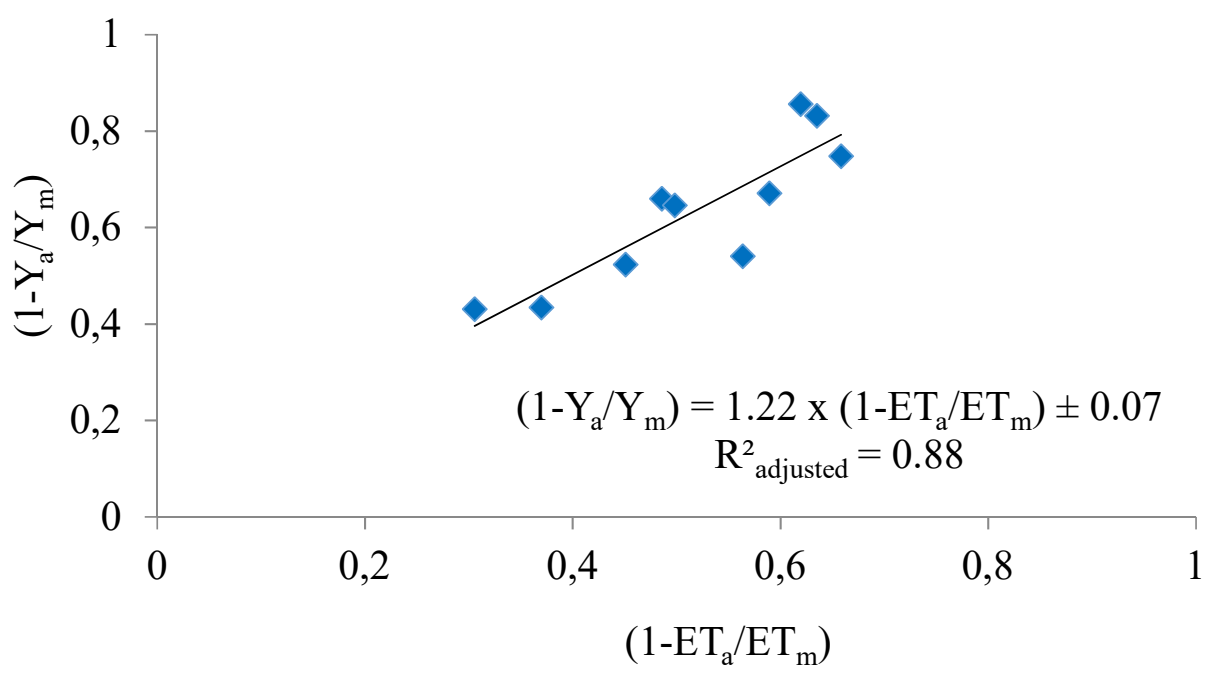

FIGURE 1. Adjustment of the yield response factor $\left(\mathrm{K}_{\mathrm{y}}\right)$ from the relationship between the relative evapotranspiration deficit $\left(1-\mathrm{ET}_{\mathrm{a}} / \mathrm{ET}_{\mathrm{m}}\right)$ and the relative yield decrease $\left(1-\mathrm{Y}_{\mathrm{a}} / \mathrm{Y}_{\mathrm{m}}\right)$ for winter corn crop grown in the region of Dourados, MS, Brazil.

Considering that $\mathrm{K}_{\mathrm{y}}$ indicates the penalization of crop yield in relation to water deficiency in its total cycle, every $1 \%$ reduction in the evapotranspiration of the winter corn crop grown, the yield is proportionally reduced, i.e. the equivalent of $1.22 \%$. Therefore, on average, there is a reduction in evapotranspiration by $51.8 \%$, which has a great impact on reducing yield by $63.4 \%$, on average (Table 3 ). This reduction could be agronomically overcome by using irrigation, which technically justifies its use. However, it is always convenient to adopt conservationist measures in rainfed production systems for better soil water retention and its consequent use by the crop.

According to Doorenbos \& Kassam (1979), $\mathrm{K}_{\mathrm{y}}$ values lower than 0.85 indicate a kind of low sensitivity to water deficit, between 0.85 and 1 low to medium sensitivity, between 1 and 1.15 medium to high sensitivity, and above 1.15 high sensitivity. Respecting this criterion, the present study demonstrated that winter corn crop grown in the region of Dourados, is a crop with high sensitivity to water deficiency due to the determined $\mathrm{K}_{\mathrm{y}}$ value (1.22). In addition, this value was close to that recommended by those authors (1.25).

Other studies have also focused on investigating the $\mathrm{K}_{\mathrm{y}}$ value for the corn crop. Some of them have found values relatively close to those obtained in the present study. In this sense, Kipkorir et al. (2002) and Popova et al. (2006) obtained $\mathrm{K}_{\mathrm{y}}$ values of 1.21 and 1.28 , respectively. The former considered a production system irrigated by furrows in a medium textured soil in a semi-arid region of Kenya. The later used 19-year data of independent experiments, all conducted in a Vertisol of one of the driest agricultural regions of Bulgaria, the region of Thrace. The diversity of experiments involved rainfed treatments and varied irrigation water management.

On the other hand, some studies have found $\mathrm{K}_{\mathrm{y}}$ values below those obtained here. In this sense, Bouazzama et al. (2012) and Irmak et al. (2016) found $\mathrm{K}_{\mathrm{y}}$ values of 1.12 and 1.14, respectively. Bouazzama et al. (2012) worked with flood-irrigated silage corn in a semi-arid region of Morocco during two seasons. Their experiments also included five management levels, varying water replenishment from 20 to $100 \%$ of the crop evapotranspiration. In a study carried out in the state of
Nebraska, the United States, Irmak et al. (2016) evaluated four seasons and six water management, namely rainfed, three deficit irrigation systems, one full irrigation system, and one irrigation system $25 \%$ higher than the recommended.

However, $\mathrm{K}_{\mathrm{y}}$ values higher than that determined in the present study have also been obtained. Djaman et al. (2013) studied corn grown in the state of Nebraska in one of the most irrigated regions in the United States, where corn predominates. They conducted, during two years, experiments that involved the rainfed treatment, as well as four levels of center pivot irrigation, one of them of full irrigation and the other with deficits. Thus, they obtained a $\mathrm{K}_{\mathrm{y}}$ value equal to 1.82. Also in Nebraska, Payero et al. (2008) studied corn grown in a semi-arid climate region. They irrigated corn for two years through buried drip and applied eight water treatments. Under these conditions, these authors determined a $\mathrm{K}_{\mathrm{y}}$ equal to 1.58 .

Although different $\mathrm{K}_{\mathrm{y}}$ values have been reported in the literature, corn is, in fact, a crop of high sensitivity to water stress. This is justified by the studies presented here, which presented $\mathrm{K}_{\mathrm{y}}$ values ranging from 1.12 to 1.82 . Obviously, it occurs because corn is a plant of $\mathrm{C} 4$ metabolism, avid for water, high temperatures, and solar radiation and, in fact, $\mathrm{K}_{\mathrm{y}}$ values above 1.15 seem to be considered more reasonable for this crop.

\section{CONCLUSIONS}

The winter corn crop, grown in the region of Dourados-MS (Brazil), showed high sensitivity to water deficit, as shown by its high $\mathrm{K}_{\mathrm{y}}$ value (1.22).

\section{REFERENCES}

Allen RG (1996) Assessing integrity of weather data for reference evapotranspiration estimation. Journal of Irrigation and Drainage Engineering 122(2):97-106. DOI: https://doi.org/10.1061/(ASCE)0733-9437(1996)122:2(97)

Allen RG, Pereira LS, Raes D, Smith M (1998) Crop evapotranspiration: guidelines for computing crop water requirements. Rome, FAO. 300p. 
Amaral JAM, Motchi EP, Oliveira H, Carvalho Filho A, Naime UJ, Santos RD (2000) Levantamento semidetalhado dos solos do campo experimental de Dourados, da Embrapa Agropecuária Oeste, município de Dourados, MS. Dourados, Embrapa Agropecuária Oeste; Rio de Janeiro, Embrapa Solos. 68p.

Bergamaschi H, Dalmago GA, Bergonci JI, Bianchi CAM, Müller AG, Comiran F, Heckler BMM (2004) Distribuição hídrica no período crítico do milho e produção de grãos. Pesquisa Agropecuária Brasileira 39(9):831-839. DOI: http://dx.doi.org/10.1590/S0100-204X2004000900001

Bergamaschi H, Matzenauer R (2014) O milho e o clima. Porto Alegre, Emater/RS-Ascar. 84p.

Bouazzama B, Xanthoulis D, Bouaziz A, Ruelle P, Mailhol JC (2012) Effect of water stress on growth, water consumption and yield of silage maize under flood irrigation in semi-arid climate of Tadla (Morocco). Biotechnologie, Agronomie, Société et Environnement 16(4):468-477.

Djaman K, Irmak S, Rathje WR, Martin DL, Eisenhauer DE (2013) Maize evapotranspiration, yield production functions, biomass, grain yield, harvest index, and yield response factors under full and limited irrigation. Transactions of the American Society of Agricultural and Biological Engineers 56(2):273-293. DOI: http://dx.doi.org/ 10.13031/2013.42676

Doorenbos J, Kassam AH (1979) Yield response to water. Rome, FAO. 193p.

Fietz CR, Fisch GF, Comunello E, Flumignan DL (2017) O clima da região de Dourados, MS. Dourados, Embrapa Agropecuária Oeste. 31p. (Série Documentos, 138)

Fietz CR, Urchei MA, Frizzone JA (2001) Probabilidade de ocorrência de déficit hídrico na região de Dourados, MS. Revista Brasileira de Engenharia Agrícola e Ambiental 5(3):558-562. DOI: http://dx.doi.org/10.1590/S1415-43662001000300031
IBGE - Instituto Brasileiro de Geografia e Estatística. Available:

ftp://ftp.ibge.gov.br/Producao_Agricola/Fasciculo_Indicadore s_IBGE/estProdAgr_201606.pdf. Accessed: Nov 09, 2016.

Irmak S, Djaman K, Rudnick DR (2016) Effect of full and limited irrigation amount and frequency on subsurface drip-irrigated maize evapotranspiration, yield, water use efficiency and yield response factors. Irrigation Science 34(4):271-286. DOI: https://doi.org/10.1007/s00271-016$0502-\mathrm{z}$

Kipkorir EC, Raes D, Massawe B (2002) Seasonal water production functions and yield response factors for maize and onion in Perkerra, Kenya. Agricultural Water Management 56(3):229-240. DOI:

https://doi.org/10.1016/S0378-3774(02)00034-3

Kottek M, Grieser J, Beck C, Rudolf B, Rubel F (2006) World map of the Köppen-Geiger climate classification updated. Meteorologische Zeitschrift 15(3):259-263. DOI: https://dx.doi.org/10.1127/0941-2948/2006/0130

Payero JO, Tarkalson DD, Irmak S, Davison D, Petersen J (2008) Effect of irrigation amounts applied with subsurface drip irrigation on corn evapotranspiration, yield, water use efficiency, and dry matter production in a semiarid climate. Agricultural Water Management 95(8):895-908. DOI:

https://doi.org/10.1016/j.agwat.2008.02.015

Popova Z, Eneva S, Pereira LS (2006) Model validation, crop coefficients and yield response factors for maize irrigation scheduling based on long-term experiments. Biosystems Engineering 95(1):139-149. DOI: https://dx.doi.org/10.1016/j.biosystemseng.2006.05.013

Rezende MKA (2016) Evapotranspiração, seus componentes e coeficientes de cultivo simples $\left(\mathrm{K}_{\mathrm{c}}\right)$ e dual $\left(\mathrm{K}_{\mathrm{e}}\right.$ e $\left.\mathrm{K}_{\mathrm{cb}}\right)$ do milho safrinha para a região de DouradosMS. Dissertação de Mestrado, Universidade Estadual de Maringá.

Steduto P, Hsiao T, Fereres E, Raes D (2012) Crop yield response to water. Rome, FAO. 505p 